\title{
Intermediation in Technology Transfer Processes in Agro-Industrial Innovation Systems: State of Art
}

\author{
Leidy Dayhana Guarin Manrique ${ }^{1, *}$, Hugo Ernesto Martínez Ardila ${ }^{2}$, Luis Eduardo Becerra Ardila² \\ ${ }^{1}$ School of Electrical, Electronic and Telecommunications Engineering, Industrial University of Santander, Bucaramanga, 680002, \\ Colombia
}

${ }^{2}$ INNOTEC Research Group, School of Industrial and Business Studies, Industrial University of Santander, Bucaramanga, 680002, Colombia

\author{
A R T I C L E I N F O \\ Article history: \\ Received: 16 July, 2021 \\ Accepted: 21 October, 2021 \\ Online: 23 November, 2021
}

Keywords:

Intermediation

Technology transfer

Innovation

Innovation systems

Agro-industrial innovation

systems

\begin{abstract}
A B S T R A C T
Considering the importance of addressing innovation issues that impact the development of economic sectors, this document presents the research work aimed at establishing a state of the art related to technology transfer and intermediation issues, which can be adopted in the innovation systems. In this case, the agro-industrial innovation system is taken as a reference from the perspective of a country, Colombia. Likewise, it is proposed to consider the synergy between actors such as the university and the industry, from a holistic vision of the systems. In this sense, and making use of the Scopus, Web of Science and Google Scholar databases, through the implementation of a methodology in which three main phases of search, selection and reading of scientific publications were generated, a set of documents was obtained, and through these it was possible to identify: concepts on innovation systems, aspects that intervene in transfer processes of technology especially related to the articulation of the actors that are part of the innovation systems, as well as the way in which these issues can be adopted, taking the agro-industrial sector as a reference. Thus, through this research, the existence of structural gaps in the networks of actors is highlighted as a key factor, which, when trying to be moderated through the intervention of government actors, also require the participation of intermediary innovation agents, that facilitate the articulation and flow of data, information and communication between those who develop technology and those who require these developments to mitigate a need in the productive sectors.
\end{abstract}

\section{Introduction}

This paper is an extension of the work "Innovation systems supported in technology transfer processes" that is published in 2020 International Congress of Innovation and Trends in Engineering (CONIITI) [1].

In Colombia, agribusiness is identified as a key sector for the sustainable development of the country [2], which is why the Law 1876 of 2017 has been approved, to support the creation of the National Agricultural Innovation System of Colombia where articulation, market orientation, sustainable development, associativity, intellectual property, development and innovation, and producers as research agents are highlighted as principles [3]. Additionally, this study seeks to contribute from the approach of technology transfer processes associated to the promotion of

${ }^{*}$ Corresponding Author: Leidy Dayhana Guarin Manrique, leidy2127825@correo.uis.edu.co

www.astesj.com

https://dx.doi.org/10.25046/aj060610 innovation, initiatives that seek the consolidation of actions related to the fulfillment of the Sustainable Development Goals [4], and the adoption of challenges that try to contribute to the food assurance of the population by 2050, which is contemplated to be close to 9,100 million people [5].

In this sense, it is proposed that it is from the academic and industrial actors, as well as the identification of intermediary agents, mechanisms, or tools, that actions aimed at the articulation of actors in innovation systems are adopted; and the generation of research results, as well as their dissemination and appropriation, contribute both, to the sustainable development of the territory and the strengthening of innovation activities in the agro-industrial sector. Dissemination of research results is understood as the activity that makes known to the public or interested third parties, the results of the research carried out by a knowledge-generating actors [6]. 
Therefore, and based on the importance that technology transfer processes have in the development of innovation systems of different geographical or spatial location, and sectoral scope, this work presents a set of concepts highlighting as a key aspect identified in the research carried out, the need to take into account the incorporation of innovation intermediary agents who through their contacts, networks, capacities, and experience are seen as those facilitators that can mitigate the gap of social distancing between the actors that can be part of the technology transfer processes in different sectors. Likewise, the novelty of this document is also associated with the analysis of the case of an agroindustrial innovation system that is visualized from government initiatives as a potential system to generate opportunities for articulation around innovation initiatives, which may finally arrive to have an impact in the markets.

\section{Analysis Scenario}

In the understanding of the complex nature of innovation systems in the agribusiness sector, within the framework of technology transfer processes, the intermediary agents are identified as actors of special interest for the analysis of synergies, because they assume a key role in the articulation of the various actors that make up these systems [7]. In this regard, universities should disseminate their research results through their technology transfer offices, which can contribute or be aligned with the needs and requirements of the industry. However, there are barriers related to the connections or articulation between actors of an innovation system [8], which hinder the development of dissemination activities.

Likewise, and based on the interaction between the university-industry-goverment and civil society actors that are part of the innovation systems [9], there are other barriers identified in the literature, which at a technological level hinder the implementation of activities of innovation-oriented to generate products and services with added value in the markets. One of the barriers is the asymmetry of information, which refers to the fact that both, the receiver and the sender in a technology transfer process do not have complete information on the technology developed and its exploitation possibilities to be able to reach a transfer agreement that satisfies the parties involved [10].

Based on the above, it is possible to identify problems associated with the knowledge and information necessary to establish a common language among the actors that participate in the technology transfer processes [9], which can lead, for example to lack of financing for technological development by potential investors, and the low opportunity for commercialization of technologies from universities.

Consequently, it is proposed that the lack of articulation of actors such as the university and industry in an innovation system, can negatively influence the generation of information flows between these two actors and, consequently, raise the levels of information asymmetry in a technology transfer process.

\footnotetext{
${ }^{1}$ For more information: https://guiasbuh.uhu.es/Google_Scholar_Citations/Ventajas_y_desventajas_de _GSC

\section{Methodology}

The results obtained in this work have been framed in the execution of the phases presented in Figure 1.

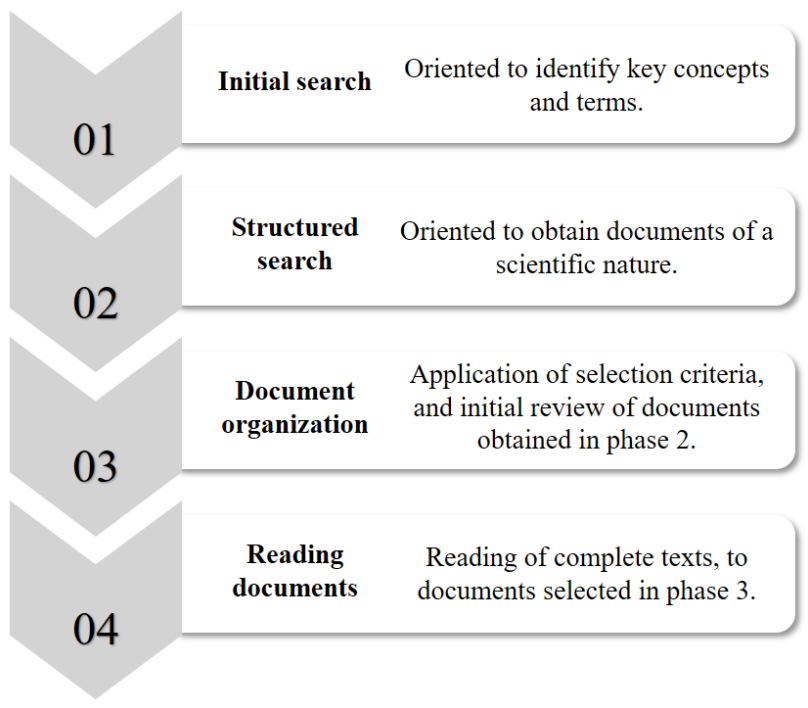

Figure 1: Research methodology..

In the first phase, the search for information was carried out with the purpose of identify the first set of documents related to technology transfer and intermediation in innovation systems. Consequently, from this information, key terms were identified for structuring the search equation and relevant authors on the aforementioned topics. In this search, the Google Scholar ${ }^{1}$ tool was used, understanding that it is a global search engine that is constantly being updated, and in which recognized authors and leading institutions in the publication of various topics can be identified.

In the second phase, the selection of the specialized databases Scopus and Web of Science was carried out ${ }^{2}$. These databases are considered robust in the global scope of publications they handle, as well as the multidisciplinary of the areas they cover, which allows addressing the issue of intermediation in technology transfer processes in a broad way. Likewise, it is highlighted that both Scopus and Web of Science handle quality documents, that is, the documents that are published are reviewed and validated by experts.

The search was executed on October 26, in 2019, and the used general equation was: TITLE-ABS-KEY (("technolog* transfer" OR "know* transfer" OR "technolog* exchang*" OR "know* exchang*") AND ("structur* mediat*" OR intermediar* OR gatekeep* OR broker* OR liaison* OR betwenness OR bridg* OR mediat* OR coordinat*) AND (universit* OR academic) ). The selection criteria applied to the results of this review were: 1) Spanish and English languages; 2) Include indexed articles in peer-reviewed scientific journals; 3) Articles belong to the citation databases: Social Sciences Citation Index (SSCI); 4) Select documents that are classified as articles or reviews, foreseeing that

\footnotetext{
${ }^{2}$ For more information: https://www.recursoscientificos.fecyt.es/licencias/productos-contratados/wos
} 
they must necessarily be reviewed by peer reviewers, representing an aspect of quality.

In the third phase, the results were grouped into two sets, which were: (i) Documents in the period from 2017 to 2019, which were read title and abstract, to select those associated with the subject under study, giving a total of 15 documents to be read completely; and, (ii) Documents obtained by adding (rev * OR meta *) to the equation, to which the title and summary were read to select those associated with the subject under study, giving a total of 52 documents that would be completely read.

In the last phase of the methodology, the complete documents were read, and information related to the topics of innovation systems, technology transfer, agro-industrial innovation systems, and intermediation was obtained. Finally, government-type sources associated with science, technology, and innovation issues and the agro-industrial sector in Colombia were reviewed.

In short, the protocol of the review to identify works associated with technology transfer and intermediation processes, included the following steps:

- $\quad$ Preliminary search in the Google Scholar database in order to identify relevant studies and keywords.

- Definition of keywords to search, establish and refine the search equation.

- $\quad$ Search for information in Web of Science and Scopus.

- Categorization and tabulation of results, including the number of publications according to countries, years, areas, in addition to the analysis of the most relevant journals, authors and keywords, in order to identify the guidelines followed by research on the subject of interest.

- Identification of articles to be analyzed applying the selection criteria, by reading the abstracts, titles and keywords.

- $\quad$ Reading and analysis of the documents.

\section{State of the Art}

Based on the results obtained from the methodology, two approaches have been found; the first, associated with the behavior of scientific knowledge as well as those publication sources that are relevant when reviewing works associated to the subject, and secondly, the most relevant issues associated with the action of the intermediary agents in technology transfer processes.

\subsection{Scientific publications}

On the one hand, regarding scientific publications, as reflected in Figure 2, technology transfer issues and intermediation actions related to the aforementioned processes have gained momentum during the last decade, highlighting the years 2017 and 2018 (until the moment of the search) as those spaces of time where the researchers found the topic more relevant. An example is found in the university context, where through intermediary agents such as their technology transfer offices, they seek to bring the inventions developed in the academy to the markets [9].

\footnotetext{
${ }^{3}$ For more information: https://www.springer.com/journal/10961 www.astesj.com
}

On the other hand, with respect to the most prominent journal sources obtained from the Scopus and Web of Science search, are shown in Table 1.

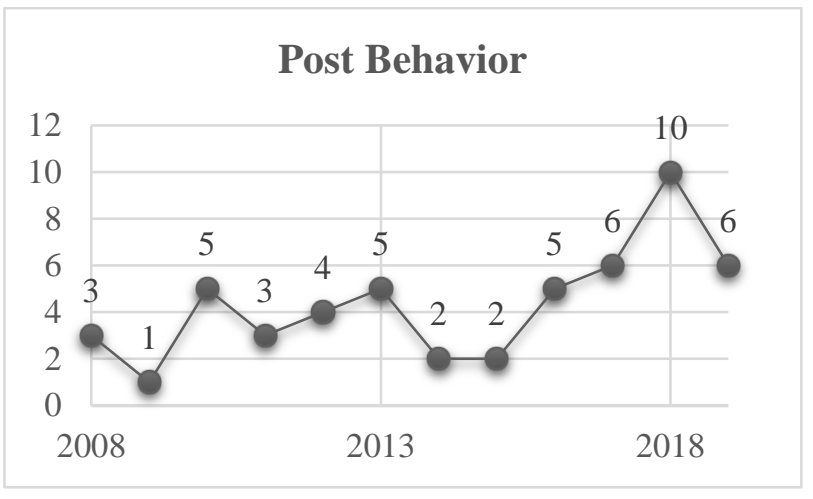

Figure 2: Publication in the time. Own elaboration based in Scopus and Web of Science.

Table 1: Most Outstanding Publication Sources. Own elaboration based in Scopus and Web of Science.

\begin{tabular}{|c|c|}
\hline Source title & $\begin{array}{c}\text { Number of } \\
\text { Publications }\end{array}$ \\
\hline Journal of Technology Transfer & 5 \\
\hline Journal of Knowledge Management & 4 \\
\hline Administrative Sciences & 2 \\
\hline $\begin{array}{c}\text { Technology Analysis \& Strategic } \\
\text { Management }\end{array}$ & 2 \\
\hline $\begin{array}{c}\text { Technological Forecasting and Social } \\
\text { Change }\end{array}$ & 2 \\
\hline
\end{tabular}

Regarding the Journal of Technology Transfer $^{3}$, it is identified that its focus is given by issues related to the study of technology transfer, from multiple dimensions of analysis, which can range from the identification of cases to issues of regulations or policies associated to technology transfer processes.

Another journal that has been highlighted is the Journal of Knowledge Management ${ }^{4}$ which relates mainly to knowledge management and innovation derived from different analysis contexts.

the following section is presented based on the results obtained from reading the documents found in the search for information, including those mentioned in the previous journals and during the period from 2008 to 2021.

\subsection{Key information identified}

For this second part, the following information compendium has been proposed, related to the topics of technology transfer, intermediation and agro-industrial innovation systems.

\subsubsection{Technology Transfer}

Technology transfer is understood as the process in which knowledge and technologies are disseminated between a holder and an interested party to be appropriated, used, or exploited [11],

\footnotetext{
${ }^{4}$ For more information: https://www.emeraldgrouppublishing.com/journal/jkm
} 
[12], [13], generally seeking to be brought to the market [14], in exchange for an incentive or monetary value [15].

Within the framework of these technology transfer processes, the following factors are taken into account: the generation of innovation in organizations [16], social capital [17] involved in the social networks of the actors who participate in the technology transfer [18], their interactions [19] and their previous relationships [20]; the university-industry relationships [21], the formality of the process (which can be formal or informal) according to knowledge management and the interactions between actors [17], [22], the limits of organizations and incentives [23], economic benefits e.g. profits on patents [24], technological cooperation between organizations [24], patents seen as a transfer mechanism [18], [25], the business culture that universities can adopt [21], the option of allowing students to participate in industry [17], the culture of the parties [17], legal frameworks [24], the uncertainties of innovations involved in technology transfer processes [26], and the importance of considering the intellectual property in the processes [13], [27]. This intellectual property can be seen materialized in the adoption of technology transfer mechanisms such as the creation of spin-off, patent licensing, collaboration actions between academia and industry [28], and the training of professionals with knowledge that contribute to the solution of industry needs [29].

Besides, when seeking to identify whether the technology transfer has been successful or not, it is found that depends of the accumulation or assimilation of knowledge in organizations that adopt the technologies that have been transferred [17]. In turn, at the macroeconomic level, technology transfer can be measured through business creation and job creation [30]. Additionally, other ways of identifying the success of technology transfer have been through the licensing of inventions [20], [24], incentives for personnel who participate in technology transfer processes [23], the indicators of patent families [24], and knowledge intensive entrepreneurship at universities [30].

However, in addition to factors in the technology transfer process, barriers are also identified that should be mitigated, some of these are: the lack of incentives from universities [9] and industry [16], cognitive and organizational distances between the university and industry [20], the time required to implement technological development activities, absorption capacity, the characteristics of knowledge, context and actors, and the culture of the parties participating in the process [17], the common language between the actors [9], the level of trust [17], [31], and the asymmetries of information between the parties [32], [33].

Finally, based on both the factors and the barriers that must be managed, it is necessary to understand that among the actors and medium involved in the process, it is possible to distinguish the sender that seeks to transfer the technology to a receptor, through a medium or mechanism, known as a channel [12]. In some scenarios, the channel may not exist, generating in the aforementioned process, a structural void that indicates the need for an agent to mitigate the gap in the flow of information, knowledge, and technologies between those who participate in the technology transfer processes. This agent is known as an intermediary [34], [35].

\subsubsection{Intermediaries in the technology transfer}

Intermediaries are agents that connect the components that structure an innovation system [36], also known as facilitators [37], who within their objectives seek to optimize interaction [38] to generate trust among the system's actors [39], strengthen interrelation processes, and at the same time mitigate the structural gaps that are identified in the social network of its actors [34].

At a general level, intermediaries are recognized as actors of special interest in innovation systems, for their intervention in actions aimed at mitigating barriers in technology transfer processes. They have key elements that help to the technology transfer process such as contacts, previous relationships with inventors, and experiences in technology commercialization [20]. In the case of the academic context that seeks to transfer technology to the industrial sector, the commercialization processes of the research results of a university, are more probable to achieve if there are links with industry [40]. In some cases, these links can be facilitated through the intervention of intermediary agents.

Thus, with regard to intermediation, the following variables have been analyzed in studies associated to the articulation between the university and industry actors: the experience of the technology transfer offices, which influences research and development agreements in the university [41], the previous relationships between intermediary agents and actors that participate in technology transfer processes [20], the performance of knowledge transfer offices measured through a number of supported patent applications, monetary income obtained from university-industry collaborations, and the creation of spin-offs [42], the efficiency of the technology transfer offices of the universities based on their age [43], [44], and the performance of technology transfer offices measured through support in licensing, patenting and Spin-off creation activities [45].

An example of intermediation is the case of technology and science parks. They support the creation of networks, especially those where university plays an important role due to both its link to the park and the legitimacy they provide to companies through their image of reliability and reputation [46]. Another example are the technology transfer offices, which within their functions provide advice on legal protection issues [45] of the technologies that are waiting to be brought to the market, in addition to providing support in the creation of technology-based companies, technological marketing [45], and assessment and due diligence in commercialization tasks of technological developments.

However, some studies have focus on the idea that an intermediary agent could only have a particular interest in obtaining economic benefits from technological results [37], beyond considering its action as positive in aspects of knowledge transfer, articulation [7] and interaction [47]. Consequently, the purpose of the intermediary agent could be an important barrier that has been associated to their nature, whether they really seek to generate linking actions, or simply act with individual commercial or political interests [48].

Therefore, it is from the nature of the intermediary agents and the objective they pursue, that they act in the configuration of the different innovation systems, especially when taking into account 
the different barriers that limit the successful result in terms of technology transfer [20].

\subsubsection{Agro-industrial innovation systems}

The concept of agro-industrial innovation systems considers the definition of a system that refers to the set of components that are interrelated with a defined objective in a given context [49], in accordance with the synergy that it experiences [50], [51]. Furthermore, when systems are complemented with the term innovation, they open the space to identify the possible achievement of competitive advantages [52]. When it comes to competitive development issues in the countries, innovation should be aimed at promoting the transfer of knowledge to reality considering the results of research, observation, discoveries, or intuitions that are generated in the nation [53].

Therefore, the conceptualization of innovation systems is open and unfinished [54]. However, some characteristica are critical such as it incorporates actors of different nature with the purpose of exchange of technologies [55], have different scope at the geographical or sectoral level [51], [56], [57] it is associated with social networks [58], and other aspects such as synergy management [58], knowledge management processes [59], [60], and the procurement of economic advantages [61].

In the case of sectoral innovation systems, which are those of interest for this research associated with the agro-industrial sector, the following stand out:

- Actors are related based on the economic sector to which their activities are associated [62].

- A differential element of these systems is the knowledge associated with innovation processes [63] in the sector.

- The key factor for the development of these innovation systems is the group of companies involved in accordance to the conditions of the sector [64].
- A set of elements of interest that sustains the development of innovation systems at the sectoral level are related to social networks, capacities of industry actors, the policies that direct their development [65], assimilation and knowledge dissemination [66], and finally, the supply chain [67].

According to the analysis level different study dimensions can be proposed as possible approaches to understand the innovation processes and its possible obstacles [53].

A representation of the set of dimensions and elements that can be considered for study purposes of innovation systems in the agro-industrial sector, and that have been previously adopted in the research activities [68], [69] in Colombia, can be seen in Figure 2.

Figure 2 shows that the dynamics of the innovation system is supported by the integration of different elements, such as a specific context, dimensions that make it possible to study the dynamics of the system from different perspectives, agents that externally intervene in the system, system behavior, and a set of interrelated actors represented under the concept of the quadruple helix [70] within the framework of a knowledge economy [71], [72]. These interrelationships are shown as a key attribute of the system, since from them, it is possible to identify realities of the different sectors [53] and generate networks or strengthen those that already exist, thus enabling information flows, knowledge and technology transfers, the realization of agreements, the establishment of collaborations, and articulation actions organized around a purpose. However, these interrelationships may require the intervention of facilitating agents, which generate links between the actors of the system [39], [73], [74]. These agents identified as intermediaries, facilitate the creation of networks of actors promoting collaboration and the flow of knowledge and information [20], [36], [37], [39], [42], [75]-[82].

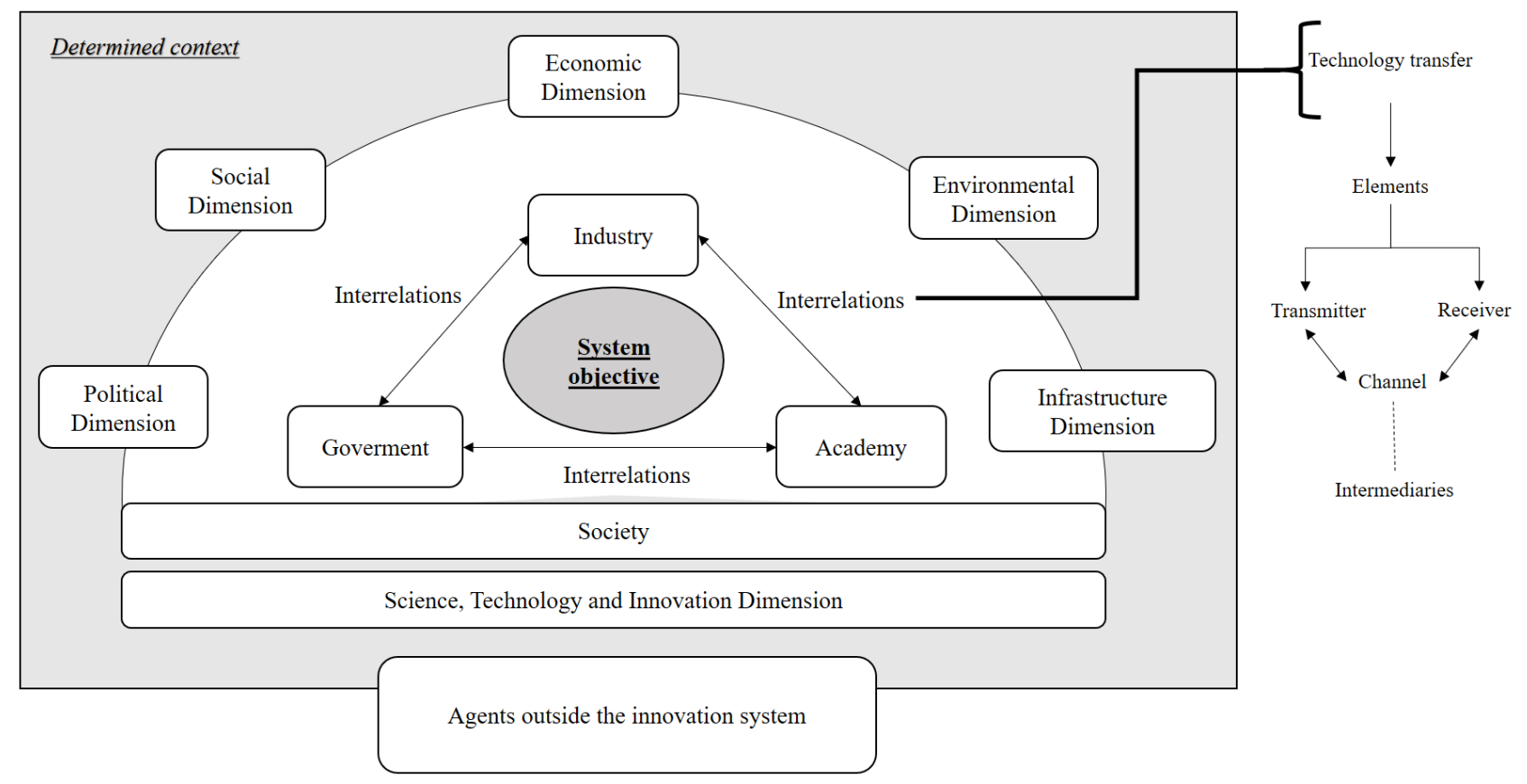

Figure 3: Dimensions and elements in innovation systems. Based on [53], [69]. 
Based on what is illustrated in Figure 2, it is found that there are similarities with other models of innovation systems, (e.g. the Tropical Agriculture Platform) [83]. The following are highlighted as common key elements:

- The proposal of a specific context, made up of institutional actors and innovation policies, which interact to achieve innovation objectives applied to the agricultural sector. In this regard, public and private research and technological development organizations stand out as key actors [22].

- The existence of institutions that act as intermediaries between the actors that carry out research, and the industry that commercialize the research output. An example is the technology transfer offices, whose mission is to promote technology-based entrepreneurship [74], [77], [84], [85], facilitate the commercialization of knowledge, manage intellectual property [9], [86], provide advice on inventions, manage academic human capital, promote contract research and promote articulation between the different actors of the university, industry, and government [86].

- Interaction with actors from other sectors, which according to their own purposes come to influence the synergy of innovation activities that take place in the sector system.

- The proposal of a political dimension, which guides both the planning and the execution of the guidelines that regulate the synergy of the system.

From the articulation of actors in the innovation systems, the sectoral innovation system like the agro-industrial, can achieve results in processes of diffusion, adoption, and appropriation of technologies among the university, industry, government, and society in general.

In addition, the value of including intermediary agents in technology transfer processes is also recognized, anticipating the possible existence of gaps in terms of social networks that emerge from the dynamics of these systems, understanding that within their role as articulatory agents, they allow generating a higher level of cohesion in the relationship of the various actors in the system.

\section{Discussion}

Faced with the development of innovation processes and technological management, in 2019 Colombia ranks 67th out of 129 countries in the global innovation index, from which aspects such as infrastructure, market, business sophistication, institutions, knowledge and technology production, human capital, researching, and creative production, were analyzed [87], [88]. In addition, as a result of this evaluation, in terms of collaboration activities between the university and the industry to develop research, the country ranks third in the Latin American region [88]. In the same orientation towards technology management processes, at the national level, it finds that most of the innovations in Colombia are developed from the research actions of the universities [89].

However, despite identifying that innovation represents an opportunity for economic development, the country requires an optimal infrastructure and necessary conditions to carry out technology transfer processes. In addition, it was identified in the science, technology, and innovation policies, that there is a low level of intermediary agents such as technology transfer offices, incubators, and science and technology parks, which by their nature support the linkage, interaction, and flow of information and knowledge between the actors of the quadruple helix [90]. The existence of a low capacity of the industrial sector to articulate and transfer knowledge and technologies among the actors of the innovation system in Colombia is pointed out in this policies. Thus, in the national development plan of Colombia, it is identified that only $3.8 \%$ of companies work collaboratively with universities, a figure that has influenced the proposal to reach a goal of 59 technology transfer agreements between the university and the industry in the country, in the period 2018-2021 [91].

From the approach of sectoral innovation systems associated with agribusiness in Colombia, the Strategic Plan for Agricultural Science, Technology and Innovation has been established [92], which takes into account the need to generate strategies aimed at promoting programs of transfer and adaptation of technologies associated with the different productive sectors, in which the proposal of mechanisms oriented to generate articulation between the different actors of the agricultural innovation system should be included. In this sense, from the Colombian Agricultural Research Corporation (Agrosavia), the Ministry of Agriculture and Rural Development of Colombia, and the Ministry of Science, Technology, and Innovation of Colombia, in the formulation of the Strategic Plan for Agricultural Science, Technology and Innovation [92], formulate two actions focusing on science, technology and innovation in the area of technology transfer, technical assistance and innovation [92], which are: (i) "the development, adjustment, and validation of extension tools and specialized comprehensive technical assistance ", and (ii) "the generation of collaborative workspaces through territorial innovation systems".

Based on the previous approaches, and understanding the value chain made up of the primary sector associated with agricultural activities, and the secondary sector related to agribusiness activities, the Santander agro-industrial innovation system is proposed as an example, in which numerous technological developments and research results carried out by universities have been identified, which tend to be unknown by the sector and have not had the possibility of being commercialized, particularly due to the lack of articulation between the actors that are part of the innovation system [93]. In addition, there are shortcomings in the information flows required from both the receiver and the sender side, to develop technology transfer processes from the university to the agro-industrial sector.

Another case of the agricultural sector in which similar problems have been studied in technology transfer processes, and in which the intermediary actions of science parks, technology transfer offices, consultants, and in general, intermediary innovation agents have favored its mitigation in the productive and market contexts, is reflected in the Dutch case [37] where intermediaries act as facilitators or forgers of networks of actors that interact under the synergy of transfer processes.

Based on the above, it is necessary to understand that when technology transfer processes are developed, elements associated with information and knowledge are involved. Therefore, it is 
necessary to take into account the existence of cognitive differences between the actors who seek to interrelate [80] around these processes. These cognitive differences can be related to the information asymmetry barrier, since it represents the gaps in terms of the information that a technology owner requires to determine the interest of a second party in its appropriation, as well as the information that the recipient needs to adopt it [10] and therefore use, exploit or commercialize it. In this sense, this barrier can lead to inefficiencies in technology commercialization activities between the university and industry [94].

Overcoming the asymmetry of information can facilitate the investment activities of industry players in the technological developments of the university, which can be considered as university ventures [95], thus opening the possibility of promoting commercial management actions among inventors or holders of technological developments and representatives of the industry, where intellectual property rights play a key role [20].

Additionally, it is important to bear in mind how the information asymmetry barrier is mitigated in the technology transfer process between the university and the industry, and how it will depend on the inventors' ability to disseminate [74], the absorption capacity of industry representatives [96], and the participation of intermediary agents that moderate information flows.

Therefore, it is proposed that the experience in commercialization and the social networks of intermediaries, as well as their previous relationships with inventors, can help reduce the information asymmetry between the senders and recipients of a technology transfer process [20]. In the case of universities among the factors that can be taken into account in the process of reducing the level of asymmetry of information is its prestige, since it generates more trust among the actors of the different economic sectors [97].

\section{Conclusions}

Based on the information presented above, it is necessary to highlight the importance of encouraging the different actors of the agribusiness innovation systems, to develop articulation that in addition of being focused on technology transfer processes, also generate alliances between the university and the industry, both in research processes and in the dissemination and exploitation of their results. Likewise, and anticipating the possible existence of structural gaps in the social networks of these systems, the option of identifying and interacting with intermediary actors is proposed as an alternative, understanding that their intervention in the technology transfer processes between the university and the industry can be assumed as a strategic factor that would contribute to the economic development of a region.

In front of this scenario, it is also necessary for government sector actors to contribute to the strengthening of the synergy of innovation systems, through regulatory mechanisms focused on expanding articulation actions and alliances between the actors of the aforementioned systems, to promote territorial development from the different economic sectors of the regions.

When it comes to contributing to economic sectors, including the agro-industrial sector, innovation is evidenced as a key factor in strengthening the markets. In addition to generate competitive advantages in the market, it can be associated to the processes of technology transfer between the university and the industry. A whole development takes place that starts from the scientific research and matures until reaching a viable product or service to be offered to the industry. Therefore, in this scenario, it is proposed that the university should have capacities to disseminate its technologies, and the industry must have capacities to adopt the technologies that are transferred to it, the foregoing to achieve, as a result, the use, exploitation, or commercialization of inventions and technological developments generated by universities.

In addition, the level of connectivity that the actors representing the university and industry can achieve also affects technology transfer processes, which is influenced by the asymmetry of information generated by the parties involved in the process of technology transfer, which is why an agent that acts as an intermediary between the university and the industry is identified as a third actor, that manages to moderate the asymmetry of information and at the same time make the transfer process effective by facilitating the flow of information between the parties involved in the process.

Based on the above, and on what was stated during the document, it is necessary to take into account that technology transfer processes can use different mechanisms that range from the creation of spin-offs to the generation of agreements between universities and companies, where the human capital of the universities brings their knowledge to the industry and reinforces their capacities through the presumption of real market scenarios. However, it is also relevant to understand that technology transfer processes include a set of factors and barriers that must be viewed from a multidisciplinary approach, for which hybrid capabilities between the university and industry require an effort to be developed by the actors that participate in these processes, thus allowing the intervention of intermediary agents who, due to their nature, can support the management of actions against the factors and barriers mentioned.

\section{Future work}

It is recommended to generate research actions around topics such as:

The evaluation of the effect generated by the different types of intermediary actors in the technology transfer processes in the agro-industrial sector, and also in other sectors of interest to the various actors that make up the innovation systems at the national, regional, or sectoral level.

Generate alliance options around various research and technological development projects, executed between the university and the industry, in such a way that their effectiveness can be evaluated in terms of technology transfer processes.

The dissemination of the results that the different types of intermediary agents have achieved in technology transfer processes, in such a way that in the second phase of this activity, an initial set of indicators can be proposed that allow measuring the impact of the intervention of these actors in the development of the systems of innovation. 
Regarding future lines of research, it is important to focus towards the study of the nature of the actors that are part of the technology transfer processes, in such a way that it can be evidenced the types of academic, industrial and hybrid capacities that allow facilitating the transfer of inventions that are developed in the university to the market.

Another alternative study is identified in the need to generate university-industry articulation methodologies, in which the objective is to identify market challenges that can be developed by the academy.

\section{References}

[1] L. Guarin, H. Martínez, "Innovation systems supported in technology transfer processes," in 2020 Congreso Internacional de Innovación y Tendencias en Ingeniería (CONIITI), 1-9, 2020, doi:10.1109/CONIITI51147.2020.9240319.

[2] DANE, "Boletín técnico - Producto Interno Bruto PIB -Cuarto trimestre de 2017,” 28, 2018.

[3] MinAgricultura, Ley 1876 por medio de la cual se crea el Sistema Nacional de Innovación Agropecuaria y se dictan otras disposiciones. Congreso de Colombia, 29 de diciembre de 2017, 1-28, 2017.

[4] PNUD, Proyecto desarrollo económico incluyente, 2011.

[5] FAO, Cómo alimentar al mundo en 2050, 2009.

[6] J.J.S. Gil, "La difusión del conocimiento como un elemento clave de la innovación y la competitividad en el entorno universitario bajo el sistema Open Journal System (OJS),” International Journal of Information Systems and Software Engineering for Big Companies (IJISEBC), 4(1), 63-71, 2017.

[7] M. Ramirez, I. Clarke, L. Klerkx, "No Analysing intermediary organisations and their influence on upgrading in emerging agricultural clusters," Environment and Planning A: Economy and Space, 50(6), 1314-1335, 2018, doi:10.1177/0308518X17741316.

[8] AGROSAVIA, Misión para la transformación del campo. Diagnóstico en CTeI, 2015.

[9] E.S. Olaya, J. Berbegal-Mirabent, O.G. Duarte, "Performance of university transfer offices as intermediary for knowledge market development [Desempeño de las oficinas de transferencia universitarias como intermediarias para la potencialización del mercado de conocimiento]," Intang. Cap, 2014, doi:10.3926/ic.497.

[10] OMPI, Comité permanente sobre el derecho de patentes. Decimocuarta sesión., 2010.

[11] B. Bozeman, H. Rimes, J. Youtie, "The evolving state-of-the-art in technology transfer research: Revisiting the contingent effectiveness model," Research Policy, 44(1), 34-49, 2015, doi:10.1016/j.respol.2014.06.008.

[12] C. Battistella, A.F. De Toni, R. Pillon, "Inter-organisational technology/knowledge transfer: a framework from critical literature review," The Journal of Technology Transfer, 41(5), 1195-1234, 2016, doi:10.1007/s10961-015-9418-7.

[13] C.S. Hayter, E. Rasmussen, J.H. Rooksby, "Beyond formal university technology transfer: innovative pathways for knowledge exchange," The Journal of Technology Transfer, 45(1), 1-8, 2020, doi:10.1007/s10961-0189677-1.

[14] F. Donneys González, B. Blanco Campins, "La transferencia de tecnología en universidades colombianas,” Economía y Desarrollo, 157(2), 182-198, 2016.

[15] F.C. Sercovich, "Dependencia tecnológica en la industria Argentina," Desarrollo Económico, 33-67, 1974, doi:10.2307/3466047.

[16] T.D.H. Gusberti, A.C. Bretas, "Diagnosis of the market for ideas and the role of industrial associations as intermediaries in the Brazilian context," Industry and Higher Education, 32(1), 9-22, 2018, doi:10.1177/0950422217733087.

[17] C. Van Horne, D. Vincent, "Challenges in technology transfer: An actor perspective in a quadruple helix environment," The Journal of Technology Transfer, 42(2), 285-301, 2017, doi:10.1007/s10961-016-9503-6.

[18] Y. Ye, K. De Moortel, T. Crispeels, "Network dynamics of Chinese university knowledge transfer," The Journal of Technology Transfer, 45(4), 1228-1254, 2020, doi:10.1007/s10961-019-09748-7.

[19] P. D’Este, O. Llopis, F. Rentocchini, A. Yegros, "The relationship between interdisciplinarity and distinct modes of university-industry interaction," Research Policy, 48(9), 1-57, 2019, doi:10.1016/j.respol.2019.05.008.

[20] Y.-C. Kim, M. Rhee, R. Kotha, "Many hands: The effect of the prior inventor-intermediaries relationship on academic licensing," Research Policy, 48(3), 813-829, 2019, doi:10.1016/j.respol.2018.11.007.
[21] P. Centobelli, R. Cerchione, E. Esposito, "Exploration and exploitation in the development of more entrepreneurial universities: A twisting learning path model of ambidexterity,” Technological Forecasting and Social Change, 141, 172-194, 2019, doi:10.1016/j.techfore.2018.10.014.

[22] S. Zaichenko, "The human resource dimension of science-based technology transfer: lessons from Russian RTOs and innovative enterprises,” The Journal of Technology Transfer, 43(2), 368-388, 2018, doi:10.1007/s10961017-9567-y.

[23] S. Horner, D. Jayawarna, B. Giordano, O. Jones, "Strategic choice in universities: Managerial agency and effective technology transfer," Research Policy, 48(5), 1297-1309, 2019, doi:10.1016/j.respol.2019.01.015.

[24] C. Martinez, L. Bares, "The link between technology transfer and international extension of university patents: Evidence from Spain," Science and Public Policy, 45(6), 827-842, 2018, doi:10.1093/scipol/scy008.

[25] D. Chatterjee, L. Leisyte, S. Dasappa, B. Sankaran, "University research commercialization in emerging economies: A glimpse into the 'black box,"” Science and Public Policy, 45(3), 361-372, 2018, doi:10.1093/scipol/scx066.

[26] N. Baines, H.L. Smith, "Key driving factors for product and service innovations in UK university spin-offs," Industry and Higher Education, 33(3), 161-171, 2019, doi:10.1177/0950422219825579.

[27] G.A. Van Norman, R. Eisenkot, "Technology transfer: From the research bench to commercialization. Part 1: Intellectual property rights - basics of patents and copyrights,” JACC: Basic to Translational Science, 2(1), 85-97, 2017, doi:10.1016/j.jacbts.2017.01.003.

[28] J. González, Manual de transferencia de tecnologia y conocimiento, The Transfer Institute, 2011.

[29] A. Anduaga, "The engineer as a 'linking agent' in international technology transfer: The case of Basque engineers trained in Liège,” Engineering Studies, 3(1), 45-70, 2011, doi:10.1080/19378629.2010.550922.

[30] F. Iqbal, P.C. Hung, F. Wahid, S.M.Q.A. Mohammed, "A glance at researchdriven university's technology transfer office in the UAE," International Journal of Technology Management, 78(1-2), 70-87, 2018, doi:10.1504/IJTM.2018.093939.

[31] E. De Wit-de Vries, W.A. Dolfsma, H.J. Van der Windt, M.P. Gerkema, "Knowledge transfer in university-industry research partnerships: a review," The Journal of Technology Transfer, 44(4), 1236-1255, 2019, doi:10.1007/s10961-018-9660-x.

[32] N.T. Gallini, B.D. Wright, "Technology transfer under asymmetric information," The RAND Journal of Economics, 147-160, 1990, doi:10.2307/2555500.

[33] J.-W. Min, N.S. Vonortas, Y. Kim, "Commercialization of transferred public technologies," Technological Forecasting and Social Change, 138, 10-20, 2019, doi:10.1016/j.techfore.2018.10.003.

[34] M. Fritsch, M. Kauffeld-Monz, "The impact of network structure on knowledge transfer: An application of social network analysis in the context of regional innovation networks,” The Annals of Regional Science, 44(1), 21, 2010, doi:10.1007/s00168-008-0245-8.

[35] S. Parjanen, H. Melkas, T. Uotila, "Distances, knowledge brokerage and absorptive capacity in enhancing regional innovativeness: A qualitative case study of Lahti region, Finland,” European Planning Studies, 19(6), 921-948, 2011, doi:10.1080/09654313.2011.568804.

[36] J. Howells, "Intermediation and the role of intermediaries in innovation," Research Policy, 35(5), 715-728, 2006, doi:10.1016/j.respol.2006.03.005.

[37] L. Klerkx, C. Leeuwis, "Establishment and embedding of innovation brokers at different innovation system levels: Insights from the Dutch agricultural sector," Technological Forecasting and Social Change, 76(6), 849-860, 2009, doi:10.1016/j.techfore.2008.10.001.

[38] L. Klerkx, C. Leeuwis, "Matching demand and supply in the agricultural knowledge infrastructure: Experiences with innovation intermediaries," Food Policy, 33(3), 260-276, 2008, doi:10.1016/j.foodpol.2007.10.001.

[39] W.L. Ruíz Castañeda, S. Quintero Ramírez, J. Robledo Velásquez, "Impacto de los intermediarios en los sistemas de innovación,” Journal of Technology Management \& Innovation, 11(2), 130-138, 2016, doi:10.4067/S071827242016000200013.

[40] R. Welsh, L. Glenna, W. Lacy, D. Biscotti, "Close enough but not too far: Assessing the effects of university-industry research relationships and the rise of academic capitalism,” Research Policy, 37(10), 1854-1864, 2008, doi:10.1016/j.respol.2008.07.010.

[41] A. Caldera, O. Debande, "Performance of Spanish universities in technology transfer: An empirical analysis,” Research Policy, 39(9), 1160-1173, 2010, doi:10.1016/j.respol.2010.05.016.

[42] J. Berbegal-Mirabent, F. Sabaté, A. Cañabate, "Brokering knowledge from universities to the marketplace: The role of knowledge transfer offices," Management Decision, 50(7), 1285-1307, 2012, doi:10.1108/00251741211247012. 
[43] W. Chapple, A. Lockett, D. Siegel, M. Wright, "Assessing the relative performance of U.K. university technology transfer offices: Parametric and non-parametric evidence,” Research Policy, 34(3), 369-384, 2005, doi:10.1016/j.respol.2005.01.007.

[44] D.S. Siegel, D.A. Waldman, A.N. Link, "Assessing the impact of organizational practices on the productivity of university technology transfer offices: An exploratory study,” 1999, doi:10.1016/S0048-7333(01)00196-2.

[45] D.S. Siegel, R. Veugelers, M. Wright, “Technology transfer offices and commercialization of university intellectual property: performance and policy implications,” Oxford Review of Economic Policy, 23(4), 640-660, 2007, doi:10.1093/oxrep/grm036.

[46] L. Lecluyse, M. Knockaert, A. Spithoven, "The contribution of science parks: a literature review and future research agenda,” The Journal of Technology Transfer, 44(2), 559-595, 2019, doi:10.1007/s10961-018-09712-x.

[47] J.M. Ekboir, A.O. Vera-Cruz, "Intermediary organisations to foster the agricultural system of innovation: The Mexican Produce Foundation," International Journal of Technological Learning, Innovation and Development, 5(1-2), 111-125, 2012, doi:10.1504/IJTLID.2012.044879.

[48] H. Yang, L. Klerkx, C. Leeuwis, "Functions and limitations of farmer cooperatives as innovation intermediaries: Findings from China," Agricultural Systems, 127, 115-125, 2014, doi:10.1016/j.agsy.2014.02.005.

[49] B. Wilson, Sistemas: Conceptos, Metodología y Aplicaciones, Editorial Limusa S.A. De C.V., 1993.

[50] Y.A. Cáceres, L.C. Flórez, "Una reflexión sistémica sobre los fundamentos conceptuales para sistemas de información," Revista Colombiana de Computación, 8(1), 1-19, 2007.

[51] J. Heijs, Sistemas nacionales y regionales de innovación y política tecnológica: Una aproximación teórica, 2001.

[52] L. Mathison, J. Gándara, C. Primera, L. García, "Innovación : Factor clave para lograr ventajas competitivas,” Negotium, 3(7), 65-83, 2007.

[53] J. Sábato, N. Botana, La ciencia y la tecnología en el desarrollo futuro de América Latina, Lima, 1970.

[54] C. Freeman, Technology, policy, and economic performance: lessons from Japan, Frances Printer Publishers, 1987.

[55] E.M. Balmaseda, I.Z. Elguezabal, G.I. Clemente, “Evolución de los modelos sobre el proceso de innovación: desde el modelo lineal hasta los sistemas de innovación,” in Decisiones basadas en el conocimiento y en el papel social de la empresa: XX Congreso anual de AEDEM, Asociación Española de Dirección y Economía de la Empresa, 2007.

[56] Minciencias, Actores del Sistema Nacional de Ciencia, Tecnología e Innovación, 2016.

[57] C. Freeman, "The 'national system of innovation' in historical perspective," Cambridge Journal of Economics, 19, 15-24, 1995.

[58] L.J. Quintero-Campos, "Aportes teóricos para el estudio de un sistema de innovación,” INNOVAR. Revista de Ciencias Administrativas y Sociales, 20(38), 57-76, 2010.

[59] D.J. Spielman, Innovation systems perspectives on developing-country agriculture: A critical review, 2005, doi:10.22004/ag.econ.59692.

[60] R. Rajalahti, W. Janssen, E. Pehu, Agricultural innovation systems: From diagnostics toward operational practices, 2008.

[61] B.-Å. Lundvall, The learning economy and the economics of hope, Anthem Press, 2016

[62] P. Adams, F. Malerba, Sectoral Systems of Innovation, Oxford University Press, 2014

[63] J. Jasso Villazul, Los sistemas de la innovación como espacios regionales, sectoriales y empresariales: Características y taxonomía, 2000.

[64] M.N. Arancegui, "Los sistemas regionales de innovación: una revisión crítica,” EKONOMIAZ. Revista Vasca de Economía., 70(1), 25-59, 2009.

[65] F. Malerba, R. Nelson, "Sistemas sectoriales, alcance y desarrollo económico,” Economía: Teoría y Práctica, SPE1, 41-62, 2009.

[66] M. Amaro Rosales, M. Morales Sánchez, "La Biotecnología en México, una aproximación desde los sistemas sectoriales de innovación,” Ide@ s CONCYTEG, 5(64), 1224-1246, 2010.

[67] T. Mets, "Developing the Sectorial Innovation System of Estonian Biotechnology,” Engineering Economics., 5(50), 73-79, 2006.

[68] UIS, UNAB, UPB, INAL, Diseño de un modelo de trabajo colaborativo entre actores del sector agropecuario para el desarrollo de la Agrópolis de Santander Magdalena Medio, 2016.

[69] UIS, Findeter, BID, Agrópolis de Santander Magdalena Medio - Estudios de profundización escala diamante, 2016.

[70] O. Afonso, S. Monteiro, M. Thompson, "A growth model for the quadruple helix,” Journal of Business Economics and Management, 13(5), 849-865, 2012, doi:10.3846/16111699.2011.626438.

[71] H. Etzkowitz, La triple hélice: universidad , industria y gobierno. Implicaciones para las políticas y la evaluación, 2002.
[72] H.G.C. Castillo, "El modelo de la triple hélice como un medio para la vinculación entre la universidad y empresa," Revista Nacional de Administración, 1(1), 85-94, 2010, doi:10.22458/rna.v1i1.286.

[73] W.L. Ruíz Castañeda, Análisis del impacto de los intermediarios en los sistemas de innovación: Una propuesta desde el modelado basado en agentes, Universidad Nacional de Colombia, 2016.

[74] W.L. Castañeda Ruíz, J. Robledo Velásquez, "Evaluación del Impacto de los Intermediarios en los Sistemas de Innovación: Marco de Análisis,” in ALTEC, 1-17, 2013.

[75] H. Van Lente, M. Hekkert, R. Smits, B.A.S. Van Waveren, "Roles of systemic intermediaries in transition processes," International Journal of Innovation Management, 7(03), 247-279, 2003, doi:10.1142/S1363919603000817.

[76] J. Vereijssen, T.M. Williams, N.M. Park, M. Nielsen, N.M. Agnew, "Evaluating co-innovation principles in a fundamental bioprotection research programme addressing challenges to potato production," New Zealand Plant Protection, 70, 16-24, 2017, doi:10.30843/nzpp.2017.70.20.

[77] E. Villani, E. Rasmussen, R. Grimaldi, "How intermediary organizations facilitate university-industry technology transfer: A proximity approach," Technological Forecasting and Social Change, 114, 86-102, 2017, doi:10.1016/j.techfore.2016.06.004.

[78] N. Aguilar-Gallegos, E.G. Martínez-González, J. Aguilar-Ávila, H. SantoyoCortés, M. Muñoz-Rodríguez, E.I. García-Sánchez, “Análisis de redes sociales para catalizar la innovación agrícola: de los vínculos directos a la integración y radialidad,” Estudios Gerenciales, 32(140), 197-207, 2016, doi:10.1016/j.estger.2016.06.006.

[79] M. De Silva, J. Howells, M. Meyer, "Innovation intermediaries and collaboration: Knowledge-based practices and internal value creation," Research Policy, 47(1), 70-87, 2018, doi:10.1016/j.respol.2017.09.011.

[80] C.W. Kilelu, L. Klerkx, C. Leeuwis, A. Hall, "Beyond knowledge brokering: an exploratory study on innovation intermediaries in an evolving smallholder agricultural system in Kenya,” Knowledge Management for Development Journal, 7(1), 84-108, 2011, doi:10.1080/19474199.2011.593859.

[81] P. Kivimaa, W. Boon, S. Hyysalo, L. Klerkx, "Towards a typology of intermediaries in sustainability transitions: A systematic review and a research agenda," Research Policy, 48(4), 1062-1075, 2019, doi:10.1016/j.respol.2018.10.006.

[82] L. Klerkx, M. Schut, C. Leeuwis, C. Kilelu, “Advances in Knowledge Brokering in the Agricultural Sector: Towards Innovation System Facilitation,” IDS Bulletin, 43(5), 53-60, 2012, doi:10.1111/j.17595436.2012.00363.x.

[83] P. de A.T. TAP, Marco Común sobre el Desarrollo de Capacidades para los Sistemas de Innovación Agrícola: Documento de Síntesis, CAB International, Wallingford, Reino Unido., 2016.

[84] J.M.B. Garmendia, A.R. Castellanos, "Estructuras de intermediación para la transferencia de conocimiento universitario: las oficinas de transferencia tecnológica,” Propiedad Intelectual, 9(13), 152-176, 2010.

[85] J. Maira, J. Etxabe, P.A. Serena, "Strategies on Technology Transfer and Patents Commercialization for Nanotechnology at the Spanish National Research Council,” Recent Patents on Nanotechnology, 12(1), 45-58, 2018, doi:10.2174/1872210511666170601115516.

[86] F. Alvarado-Moreno, "El Papel de las Oficinas de Transferencia Tecnológica (OTT) en las Universidades: Una Perspectiva de la Última Década,” Journal of Technology Management \& Innovation, 13(3), 104-112, 2018, doi:10.4067/S0718-27242018000300104.

[87] Portafolio, "Colombia cae en clasificación global de los más innovadores," Portafolio, 2019.

[88] J. García, C. Gómez, C. Jiménez, J.C. Castellanos, La eficiencia de la Innovación en Colombia frente al mundo: Un análisis desde el Global Innovation Index, 2016 - 2019, 2019.

[89] Minciencias, Transferencia de conocimiento, una estrategia para potencializar la investigación, Minciencias, 2016.

[90] CONPES, Política nacional de ciencia, tecnología e innovación 2015 - 2025, 2015.

[91] DNP, Plan Nacional de Desarrollo 2018 - 2022, Https://Www.Dnp.Gov.Co/DNPN/Paginas/Plan-Nacional-deDesarrollo.Aspx, 2018.

[92] Agrosavia, MADR, Minciencias, PECTIA: Plan Estratégico de Ciencia, Tecnología e Innovación del sector Agropecuario colombiano (2017-2027), 2016.

[93] L. Guarin, E. Romero, L.E. Becerra, "Agrópolis de Santander Magdalena Medio en Colombia: Alternativa para el desarrollo rural en las regiones," in Congreso Internacional de Investigación e Innovación - Multidisciplianrio, 7382-7393, 2018.

[94] G. Abramo, C.A. D’Angelo, F. Di Costa, M. Solazzi, “The role of 
information asymmetry in the market for university-industry research collaboration," The Journal of Technology Transfer, 36(1), 2011, doi:10.1007/s10961-009-9131-5.

[95] P. Gubitta, A. Tognazzo, F. Destro, "Signaling in academic ventures: the role of technology transfer offices and university funds," The Journal of Technology Transfer, 41(2), 2016, doi:10.1007/s10961-015-9398-7.

[96] A.C. Schulze-Krogh, "Firms' Absorptive Capacity for Research-Based Collaboration—an Analysis of a Norwegian R\&amp;D Brokering Policy Program,” Science and Public Policy, 45(4), 2018, doi:10.1093/scipol/scx081.

[97] M. Cattaneo, M. Meoli, S. Vismara, "Cross-border M\&amp;As of biotech firms affiliated with internationalized universities," The Journal of Technology Transfer, 40(3), 2015, doi:10.1007/s10961-014-9349-8. 